\title{
KSZTAŁTOWANIE SIĘ NOWYCH PODZIAŁÓW SPOŁECZNO-POLITYCZNYCH \\ NA PRZYKŁADZIE TRANSFORMACJI FRANCUSKIEGO SYSTEMU PARTYJNEGO
}

\author{
SHAPING OF NEW SOCIO-POLITICAL CLEAVAGES: \\ TRANSFORMATION OF THE FRENCH PARTY SYSTEM
}

\author{
Jakub Potulski*
}

Artykuł poświęcony jest problematyce przemian zachodzących w ramach europejskich systemów partyjnych. Autor zwraca uwagę, że możemy obecnie obserwować proces rozpadu dotychczasowych podziałów socjopolitycznych i kształtowania się nowych podziałów. Proces ten jest efektem makropoziomowych procesów, które można określić jako rewolucja postindustrialna i rewolucja postnarodowa. Głównym celem artykułu jest próba weryfikacji hipotezy zakładającej, że efektem kształtowania się tzw. społeczeństwa informacyjnego będzie pojawienie się nowych podziałów społecznych politycznie doniosłych. Ponad pięćdziesiąt lat temu dwaj autorzy: Seymour Lipset i Staein Rokkan opublikowali książkę Party systems and voter alignments: cross-national perspectives. W pracy tej autorzy skojarzyli podziały społeczne z liniami podziałów politycznych kształtujących się w ramach europejskich systemów partyjnych. Lipset i Rokka dowodzili także, że istniejące podziały partyjne są
\end{abstract}

In this article the author examines changes in the European party systems. The author argues that we can observe process of decline of traditional social cleavages and the emergence of new social cleavages related to the macro-level phenomena which we can define as post-national and postindustrial revolution. The main aim of the article is to verify the research hypothesis assuming that in the highly developed societies that have reached the phase of information society development, new socio-political divisions are formed. Almost fifty year ago, Seymour Lipset and Stein Rokkan published a book entitled Party Systems and Voter Alignments: Crossnational Perspectives. In this influential piece of academic work social cleavages have been linked to the political alignments and party systems of Western Europe. The authors argued that the $19^{\text {th }}$ and early $20^{\text {th }}$-century political movements manifested national and industrial revolution. But the character of European party systems and

* Uniwersytet Gdański, Wydział Nauk Społecznych. 
efektem dwóch makropoziomowych procesów: rewolucji przemysłowej i rewolucji narodowej. Jednakże obecnie europejskie systemy partyjne przechodzą daleko idące przemiany. Można zaobserwować spadek poparcia dla „tradycyjnych” partii politycznych, a także rosnące poparcie dla tzw. ruchów antyestablishmentowych. Autor przyjął, że jest to efekt kształtowania się nowych podziałów socjopolitycznych będących efektem daleko idącej transformacji społecznej związanej z kształtowaniem się społeczeństwa informacyjnego. Dla potwierdzenia swojej hipotezy autor analizuje przemiany, które zaszły we francuskim systemie partyjnym. Według autora zmiany, które zaszły na francuskiej scenie politycznej, są dobrym stadium przypadku, które pozwala zrozumieć współczesne procesy społeczno-polityczne.

Słowa kluczowe: podziały socjopolityczne; francuski system polityczny; rewolucja postnarodowa; rewolucja postindustrialna; populizm political cleavages changed dramatically in the past twenty years. The party systems become less stable and we can observe the process of decline of the traditional socio-political cleavages and changing of structure of political conflict. French party system is one of the most interesting cases of declining of the traditional political cleavages. The results of the last presidential elections are surprising: for the first time since the founding of the Fifth Republic in 1958, two major political parties have been voted out of the race in the first round. The French elections seem to be confirming a trend of the decline of traditional parties and traditional social and political cleavages.

Keywords: political cleavages; French party system; post-national revolution; post-industrial revolution; populism

\section{WSTĘP}

Zmiany, które można obserwować w ostatnich latach w systemach partyjnych krajów zachodnioeuropejskich, są na tyle znaczące, że coraz częściej zwraca się uwagę na fakt, iż mamy obecnie do czynienia z pojawieniem się w społeczeństwie nowych podziałów politycznych społecznie doniosłych. Od czasu, gdy w latach 60. Seymour Lipset i Stein Rokkan ogłosili swoją słynną hipotezę „zamrożenia podziałów partyjnych" (por. Lipset, Rokkan, 1967, s. 44), która zakładała, że głęboko utrwalone podziały społeczne, będące efektem dziewiętnastowiecznych rewolucji: przemysłowej i narodowej, stabilizują zachowania wyborcze i redukują wyborczą niestabilność, zachodnioeuropejskie systemy partyjne przeszły daleko idącą metamorfozę. Wielu badaczy zaczęło na podstawie badań empirycznych dowodzić, że opisane przez Rokkana i Lipseta linie podziałów społeczno-politycznych nie odzwierciedlają już naszej rzeczywistości. Zaczęto udowadniać, że tradycyjne związki pomiędzy grupami społecznymi a partiami politycznymi, na które wskazywali Lipset i Rokkan, tracą na swoim znaczeniu (Por. Dalton, 
1984; Dalton, Flanagan, Beck, 1984; Clark, , Lipset, 1991; Clark, Lipset, Rempel, 1993; Franklin, Mackie, Valen, 1992; Nieuwbeerta, Ultee, 1999; de Graaf, Heath, Need, 2001; Knutsen, 2006). Empiryczne obserwacje zachowań wyborczych wskazywały na coraz łatwiejsze i szybsze przenoszenie swoich głosów przez wyborców pomiędzy partiami, znaczny wzrost liczby wyborców nie do końca zdecydowanych i podejmujących decyzję w ostatniej chwili, pojawienie się tzw. partii protestu oraz powstanie i rozwój ugrupowań reprezentujących nowy typ konfliktu politycznego związanego z rozprzestrzenianiem się tzw. wartości postmaterialistycznych (por. Inglehart, 1977). Nie oznacza to jednak, że prace Lipseta i Rokkana straciły na swojej wartości. Zaproponowany przez nich schemat analityczny zachował swoją wysoką wartość heurystyczną i w dalszym ciągu jego zastosowanie pozwala na wyjaśnianie złożonych procesów społeczno-politycznych.

Od lat 80. coraz widoczniejsza stała się stopniowa ewolucja zachodnioeuropejskich systemów partyjnych związana z kształtowaniem się nowych podziałów społecznych, które zaczęły wykraczać poza tradycyjne podziały klasowe i religijne. Pierwszy z tych podziałów związany był z problemami środowiska i doprowadził do wprowadzenia do zachodnioeuropejskich systemów partyjnych relatywnie silnych ugrupowań „Zielonych” (Green Party). Drugi z tych podziałów związany był z procesami globalizacji, a zwłaszcza z rosnącymi przepływami ludzkimi i polityzacją zjawiska migracji. Ewolucja systemów partyjnych wywołana przez te nowe linie konfliktów dotknęła większość zachodnich demokracji. Polityzacja konfliktu pomiędzy wartościami liberalnymi i etnocentrycznymi, a także pomiędzy ekologami a zwolennikami neoliberalnego produktywizmu (productivism) zmieniła dotychczasowy układ sił politycznych i wprowadziła do politycznej agendy nowe kwestie problemowe (por. Inglehart, 1984; Kriesi, Grande, Lachat, Dolezal, Bronschier, Frey, 2006, 2008; Kiresi, Grande, Dolezal, Helbling, Höglinger, Hutter, Wüest, 2012).

Ponadto na początku lat 90. pojawiły się opinie, że społeczeństwa zachodnioeuropejskie wkraczają w nową tzw. postpolityczną erę, w której tradycyjne podziały ideologiczne nie mają już znaczenia. M.in. Anthony Giddens i Urlich Becka pisali, że model polityki opartej na mocnej opozycji lewica-prawica należy już do przeszłości, gdyż był produktem tzw. pierwszej nowoczesności. Natomiast w warunkach tzw. późnej nowoczesności dyskusje powinny koncentrować się na tym, co Giddens określał „polityką życia”, a Beck „subpolityką” (por. Giddens, 2001; Beck, Giddens, Lash, 2009). Jednakże określenie „postpolityka” wzbudza liczne kontrowersje (por. Potulski, 2014), a rywalizacja polityczna nie 
zanika. Liczne obserwacje wskazują, że jesteśmy obecnie nie tyle świadkami narodzin „ery postpolitycznej”, ile raczej świadkami wyłaniania się nowych problemów, które rzeczywiście wykraczają poza dawne podziały społeczno-polityczne, ale na ich miejsca wytwarzają nowe. Pojawiają się konflikty, które nie mieszczą się w ramach tradycyjnych analiz sfery polityki. Coraz większą rolę w procesach politycznych odgrywa spór pomiędzy zwolennikami transnacjonalizacji i globalizacji a zwolennikami państwa autarkicznego, zamkniętego we własnych granicach i kulturze; pomiędzy zwolennikami „tradycyjnych” wartości a zwolennikami wartości postmaterialistycznych.

Wyłanianie się nowych podziałów politycznych można obserwować na przykładzie zmian zachodzących w ramach systemu partyjnego. Zgodnie z hipotezą Rokkana i Lipseta podziały partyjne stanowią odzwierciedlenie linii konfliktów ujawniających się w strukturze społecznej. Oznacza to, że szukając potwierdzenia hipotezy mówiącej o wyłanianiu się nowych podziałów socjopolitycznych, trzeba obserwować przemiany zachodzące w ramach systemów partyjnych wysoko rozwiniętych państw europejskich. Rzeczywiście w wielu przypadkach mamy tam do czynienia z „załamaniem” dotychczasowego układu rywalizacji politycznej i utratą znaczenia przez „tradycyjne” partie polityczne. W krajach, takich jak Francja, Włochy, Grecja, Hiszpania, dotychczas dominujące partie polityczne okazują się niezdolne do absorbcji nowych problemów politycznych wykraczających poza standardowy podział lewica-prawica. Ich problemy związane z określeniem swojej własnej tożsamości powodują, że są one wypierane przez zupełnie nowe siły polityczne, co powoduje daleko idącą rekonstrukcję układu rywalizacji politycznej. Oczywiście zachodzące zmiany nie stanowią radykalnego zerwania z przeszłością, gdyż stare podziały i tradycyjne formy lojalności partyjnych wciąż oddziałują na zachowania wyborcze. Mamy zatem do czynienia z wymieszaniem się „starych” i „nowych” podziałów socjopolitycznych, co potęguje niepewność względem przebiegu procesów wyborczych.

\section{HIPOTEZA}

Punktem wyjścia dla rozważań związanych ze współczesną transformacją systemów partyjnych jest teoria podziałów socjopolitycznych Lipseta i Rokkana. Jej zastosowanie i uzupełnienie o nowe elementy może pomóc w zrozumieniu współczesnej ewolucji europejskich systemów partyjnych. Obecnie możemy obserwować rozpad historycznych podziałów społeczno-politycznych, które 
zidentyfikowali w swoich pracach Lipset i Rokkan (por. Lipset, Rokkan, 1967). Osłabieniu uległy tradycyjne lojalności partyjne ukształtowane w ramach procesów związanych $\mathrm{z}$ europejską modernizacją i powstawaniem społeczeństw przemysłowych. Badanie zmian zachodzących w ramach systemów partyjnych ma służyć analizie procesów kształtowania się nowych podziałów społecznych i nowych linii konfliktów. Ma ona pozwolić na identyfikację makropoziomowych procesów wpływających na charakter obecnych zmian społecznych.

Są dwa dominujące sposoby konceptualizacji rozpadu dotychczasowych lojalności partyjnych. Jednym z nich jest zwrócenie uwagi na fakt, że osłabienie dotychczasowych lojalności partyjnych jest generalnie związane ze zmianą zachowań wyborczych. Współczesny wyborca dokonuje raczej krótkoterminowych wyborów ukierunkowanych na konkretne kwestie poruszane przez partie polityczne lub ukierunkowanych na konkretnego kandydata, który jest w stanie przyciągnąć uwagę wyborców. Preferencje polityczne są mniej kolektywne, a stają się kwestią indywidualnego wyboru. Partie polityczne konkurują o wyborców, starając się tworzyć „produkt” dostosowany do „rynku” wyborczego, odwołują się do rozwiązań populistycznych, a także starają się promować wyrazistych kandydatów, zdolnych przyciągnąć uwagę wyborcy. W ten sposób głosowanie staje się bardziej nieprzewidywalne, a wyborcy łatwo przenoszą swoje głosy z jednej partii na inną. Drugim sposobem wyjaśniania jest zwrócenie uwagi na zmianę charakteru politycznych konfliktów we współczesnym świecie (por. Inglehart, 1977; Kitschelt, 1988; Kitschelt, Staf, 1990; Kriesi et al. 2006, Bornschier, 2010a, 2010b; Hooghe, Marks, 2018). W literaturze związanej z tym nurtem zwraca się uwagę na pojawienie się nowych kwestii politycznych w mniejszym stopniu związanych $\mathrm{z}$ wymiarem ekonomicznym, a w większym budowanymi wokół wartości kulturowych (pojawienie się wartości postmaterialnych, masowe migracje), które generują nowe linie konfliktów politycznych.

Obydwa sposoby wyjaśniania zachodzących zmian pozwalają na zrozumienie niektórych zjawisk zachodzących w ramach współczesnych społeczeństw partyjnych, ale nie wszystkich. Transformacja systemów partyjnych wydaje się być procesem głębszym, związanym $\mathrm{z}$ wyłanianiem się nowych podziałów społeczno-politycznych, które są efektem transformacji społecznej (powstania globalnego społeczeństwa informacyjnego) i oporu wobec zachodzących zmian. Nowa struktura rywalizacji politycznej kształtuje się na bazie nowych podziałów społecznych i nowej agendy problemów politycznych. Nowe podziały społeczne mają odmienny charakter od tych, które do tej pory strukturyzowały scenę polityczną i dlatego wykraczają poza dotychczasowy układ systemu partyjnego. 
Jest to nawiązanie do teorii Steina Rokkana i jego hipotezy, która brzmiała, że istnieją zjawiska zachodzące na poziomie makro, które w największym stopniu wpływają na strukturę społeczną i podziały socjoekonomiczne, które następnie znajdują swoje odbicie w strukturze podziałów politycznych, a przede wszystkim w ramach systemów partyjnych.

Rokkan zidentyfikował dwa główne zjawiska związane z europejską nowoczesnością: rewolucję narodową i przemysłową. Rewolucje te przyczyniły się do ukształtowania się krytycznych linii podziałów społecznych (social clavages), gdyż procesy modernizacyjne wywołane przez rewolucję przemysłową i narodową wywoływały opór i kontrmobilizację grup zagrożonych procesami zmian cywilizacyjnych. Autor, nawiązując do rokkanowskiej tradycji analiz systemów partyjnych, wysunął hipotezę, że największe znaczenie dla obecnej transformacji systemów partyjnych mają dwa główne zjawiska związane z europejską „późną nowoczesnością": rewolucja postnarodowa (transnacjonalizacja) i rewolucja postindustrialna. To one są główną przyczyną ewolucji systemów partyjnych, gdyż wyznaczają nowe linie podziałów społecznych. Rewolucja postnarodowa i rewolucja postindustrialna i ich społeczno-ekonomiczne konsekwencje są głównym punktem odniesienia dla współczesnych nowych ruchów politycznych i powinny być traktowane jako podstawowe zmienne wyjaśniające na poziomie makro.

\section{METODOLOGIA BADAŃ I TERMINOLOGIA}

W celu weryfikacja hipotezy badawczej w artykule analizie zostały poddane wybory i ewolucja systemu partyjnego we Francji. Nie jest to jedyny kraj, w którym nastąpiła dekonstrukcja dotychczasowego układu partyjno-politycznego, ale wydaje się, że procesy zachodzące we współczesnej Francji wydają się być dobrym przykładem rozpadu tradycyjnego układu politycznego lewica-prawica, który strukturyzował zachodnioeuropejskie systemy partyjne od czasów zakończenia drugiej wojny światowej. Niezależnie od faktu, że procesy transformacji dotychczasowego układu sił w ramach systemu partyjnego we Francji posiadają swoją specyfikę związaną z lokalnym kontekstem, to jednocześnie ich analiza powinna pozwolić na ukazanie pewnych uniwersalnych tendencji mających swoje źródło w szerszych procesach o charakterze makrospołecznym. Ponadto wybór Francji jako studium przypadku uzasadniony jest względami praktycznymi, a przede wszystkim dostępnością danych będących efektem dwóch badań: 
1) The French Electoral Survey (EnEF 2017) - programowi realizowanemu na zlecenie francuskiego ministerstwa spraw wewnętrznych; oraz 2) French Election Study 2017 (FES 2017), będącego implementacją piątego modułu projektu Comparative Study of Electoral Systems (CSES).

Analiza nowych źródeł podziałów społeczno-politycznych odwoływać się będzie do modelu statusu społeczno-ekonomicznego (the socioeconomic status model). Status społeczno-ekonomiczny jest pomiarem wykorzystywanym przez badaczy do mierzenia pozycji ekonomicznej i społecznej danej osoby względem innych. Na potrzeby niniejszego wywodu analizowane będą jednak nie cechy indywidualne wyborców, ale przestrzenne zróżnicowanie sposobów głosowania, oraz wskaźniki społeczno-ekonomiczne regionów i prowincji. Wykorzystane zostaną także dane pochodzące z French Elections Study 2017 oraz The French Election Survey 2017, które odnoszą się problemu ideologii i wartości społeczno-politycznych strukturyzujących współczesną scenę polityczną we Francji. Wykorzystanie obydwu typów danych ma pozwolić na uzasadnienie hipotezy, że podstawowe linie konfliktów politycznych są pochodną rewolucji postindustrialnej i postnarodowej.

Problemem są kwestie terminologiczne. Zmiany zachodzące we współczesnym świecie są na tyle specyficzne, że stosowanie wobec nich dotychczasowej terminologii wydaje się mieć ograniczone możliwości heurystyczne. Dlatego też konieczne jest wypracowanie i uzasadnienie nowej siatki pojęciowej, w ramach której można by dokonać wyjaśnienia współczesnych procesów politycznych, a w tym załamania się dotychczasowej struktury systemów partyjnych w Europie Zachodniej i kształtowania się nowych podziałów społeczno-politycznych.

Po pierwsze trzeba zaznaczyć, że wobec nowych ruchów/partii politycznych, które zaczynają odgrywać coraz większą rolę w rywalizacji politycznej, używa się często określenia „partie populistyczne”. Populizm to jedno z najbardziej złożonych pojęć i zjawisk w życiu społecznym. Wątpliwe jest, czy kategoria ta może być użyteczna heurystycznie. Populizm bywa utożsamiany z pojęciem demofilii i oznacza idealizowanie ludu, może być rozumiany jako synonim demagogii albo oznaczać zakwestionowanie i odrzucenie instytucjonalnych ram działania danego systemu (Szacki, 2006, s. 15-18). Termin populizm nie jest do końca zdefiniowany i może być nadużywany. We współczesnej debacie publicznej uzyskał on pejoratywne znaczenie na określenie osoby lub partii, która mówi głównie to, co jej elektorat chce usłyszeć, ukrywając kwestie zbyt skomplikowane i trudne politycznie, i proponującej proste rozwiązania. Jednakże traktowanie zjawiska populizmu z perspektywy dewiacji jest pozbawione większej mocy 
eksplanacyjnej. Zwracał na to uwagę m. in. Ernesto Laclau, który uważał, że powinien on być konceptualizowany jako bardzo charakterystyczna i zawsze możliwa forma strukturalizacji życia politycznego (por. Laclau, 2009, s. 13-17). Na potrzeby niniejszego wywodu przyjęto ujęcie Augusta Stewarda, który uważał, że populizm stanowi odpowiedź na problemy stawiane przez modernizację i jej konsekwencje (por. Stewart 1969, s. 180). W tym ujęciu tzw. ruchy populistyczne są efektem narastającego sprzeciwu i mobilizacji przeciwko zachodzącym obecnie przemianom społecznym związanym $\mathrm{z}$ kształtowaniem się społeczeństwa ponowoczesnego/informacyjnego. Jakie zmiany są szczególnie istotnym punktem odniesienia dla agendy politycznej ruchów populistycznych? Są to przede wszystkim rewolucja postnarodowa i rewolucja postindustrialna. Oba te procesy wywołują daleko idące zmiany sposobu organizacji naszych społeczności, a tym samym generują opór i kontrmobilizację wobec zachodzących zmian. Zatem po drugie, aby zachować spójność siatki terminologicznej, wyjaśnienia wymaga przyjęty przez autora sposób konceptualizacji pojęć „rewolucja postnarodowa” $\mathrm{i}$ „rewolucja postindustrialna”. Jest to istotne ze względu na fakt, iż odgrywają one centralną rolę w zaproponowanym sposobie analizy zachodzących przemian.

Termin „rewolucja postnarodowa” odnosi się do grupy procesów związanych $\mathrm{z}$ rekonstrukcją stworzonej w dobie nowoczesności formy państwa, jaką było scentralizowane państwo narodowe, oraz z rekonstrukcją wytworzonych w dobie nowoczesności form identyfikacji określanych jako tożsamość narodowa. Rewolucja informatyczna i postępująca globalizacja odebrała rację bytu założeniu, że spójność społeczna ma - i może być gwarantowana w zupełności przez państwo-naród-kraj-społeczeństwo. Kierując się taką przesłanką, wcześniejsze pokolenia zakładały, że ludzie tworzą warunki społecznej integracji głównie za pośrednictwem terytorialnie określonej ojczyzny (Scholte, 2006, s. 350). Natomiast obecnie mamy do czynienia z transnacjonalizacją społeczeństw dokonującą się powoli w efekcie procesów integracyjnych (zniesienie granic i usuwanie innych przeszkód dla swobodnego poruszania się i pracy, „mieszanie się" narodów, wspólne przedsięwzięcia i organizacje).

Termin „rewolucja postindustrialna” odnosi się grupy procesów wywołujących strukturalne zmiany w globalnej gospodarce, a w tym przede wszystkim procesów związanych z kształtowaniem się nowego sposobu organizacji produkcji przemysłowej (rewolucja przemysłowa 4.0); oznacza przechodzenie do tzw. gospodarki opartej na wiedzy oraz globalizacji aktywności gospodarczej. Transformacja modelu gospodarczego wymusza także zmiany na rynku pracy i w polityce społecznej. Nastąpiło odejście od polityki pełnego zatrudnienia 
i inkluzyjnej polityki zabezpieczeń społecznych na rzecz elastyczności, efektywności i konkurencyjności. Gwałtowne zmiany wywołują uczucie niepokoju, a pracownicy wielu różnych zawodów odczuwają niepewność zatrudnienia, obawę zarówno o własną pozycję zawodową, jak o swoją użyteczność w miejscu pracy.

\section{EWOLUCJA FRANCUSKIEGO SYSTEMU PARTYJNEGO}

Francja jest przykładem zachodnioeuropejskiego kraju, w którym w ostatnich dekadach doszło do dekonstrukcji istniejących podziałów partyjnych i zastąpienia ich przez całkiem nowy układ rywalizacji politycznej. Ostatnie elekcje: parlamentarna i prezydencka (ostanie wybory we Francji odbyly się: prezydenckie 23 kwietnia-7 maja 2017 r., oraz parlamentarne 11-18 czerwca 2017 r.) są ciekawym studium przypadku, na podstawie którego można prześledzić zmiany zachodzące w zachodnioeuropejskich społeczeństwach.

Szczególnie w wyborach prezydenckich 2017 r. widać wyraźnie zmianę, jaka dokonała się we Francji i upadek tradycyjnych francuskich partii politycznych: socjalistów i republikanów ${ }^{1}$. Po raz pierwszy od 1981 urząd prezydencki przypadł osobie spoza nich, a co więcej - po raz pierwszy od powstania piątej republiki (1958 r.) żaden z kandydatów największych francuskich partii nie wszedł do drugiej rundy. 39-letni Emanuel Macron nie był popierany przez żadną z tradycyjnych francuskich partii politycznych, nie miał za sobą długoletniej kariery politycznej w którejś z wielkich partii politycznych, a co więcej-zaledwie na parę miesięcy przed terminem wyborów zaczął on być uznawany za kandydata, który może odnieść zwycięstwo. W drugiej rundzie Emanuel Macron uzyskał 66,1\% głosów, pokonując kandydatkę Frontu Narodowego Marine Le Pen, która uzyskała 33,9\% głosów. Wynik ten sugeruje, że dominujący przez wiele dekad układ socjaliści (lewica) versus republikanie (prawica) został zastąpiony przez relatywnie nową centrowo-populistyczną (tzw. progresywizm) oraz populistyczną - konserwatywną agendę polityczną.

${ }^{1}$ Wyniki wyborów w pierwszej rundzie w 2012 r. republikanie - 27\%, socjaliści - 29\% (razem partie „tradycyjne” 56\%) pozostałe partie 44\%. W 2017 r. republikanie 20\%, socjaliści 6\% (razem partie „tradycyjne” 26\%), pozostałe partie 74\% głosów. Odpływ wyborców od tradycyjnych francuskich partii politycznych w ciągu pięciu lat to 30 punktów procentowych. 
Analiza wyników wyborów prezydenckich ukazuje pewne interesujące zależności związane z przestrzennym zróżnicowaniem zachowań wyborczych Francuzów i pewne charakterystyczne wzory związane z socjoekonomiczną charakterystyką francuskich regionów. Terytorium europejskiej Francji podzielone jest na 13 regionów administracyjnych. Są to: Owernia-Rodan-Alpy, Burgundia-Franche-Comté, Bretania, Region Centralny-Dolina Loary, Korsyka, Grand Est, Hauts-de-France, Île-de-France (region paryski), Normandia, Nowa Akwitania, Oksytania, Kraj Loary oraz Prowansja-Alpy-Lazurowe Wybrzeże. W wyborach prezydenckich Marie Le Pen w pierwszej rundzie uzyskała 21,3\% głosów, a w drugiej 33,9\%. W pierwszej rundzie wygrała aż w ośmiu administracyjnych regionach kraju: Burgundia-Franche-Comté $(25,1 \%)$, Region Centralny Dolina Loary (23,1\%), Korsyka (27,9\%), Grand Est (27,8\%), Hauts-de-France (31\%), Normandia (23,9\%), Oksytania (23\%), oraz Prowansja-Alpy-Lazurowe Wybrzeże (28,2\%). Macron tylko w czterech: Owernia-Rodan-Alpy (24,5\%), Bretania (29\%), Île-de-France (28,6\%), Nowa Akwitania (25,1\%), Kraj Loary (26,3\%). W drugiej rundzie Macron wygrał we wszystkich regionach, gdzie okazał się kandydatem „drugiego wyboru”. Bardziej szczegółowa analiza głosowania we francuskich departamentach (mniejszych jednostkach administracyjnych) ukazuje istniejący we Francji silny podział wschód-zachód. Marie Le Pen, kandydatka Frontu Narodowego, największą popularnością cieszy się w departamentach położonych na północy, na północnym zachodzie (jedyne dwa departamenty, w których Le Pen zwyciężyła w drugiej turze wyborów - Pas de Calais oraz Aisne - mieszczą się właśnie na północy kraju), w rejonie Doliny Rodanu oraz w departamentach śródziemnomorskich. Natomiast Marcon - kandydat En Marche! - uzyskał przewagę w departamentach położonych głównie na wschodzie kraju i centrum $\mathrm{kraju}^{2}$.

Szczególnie dwie zmienne wydają się szczególnie istotne z punktu widzenia socjoekonomicznej analizy głosowania we Francji: bezrobocie, wykształcenie oraz miejsce zamieszkania. Le Pen uzyskała szczególnie wysokie poparcie w regionach z wysoką stopą bezrobocia oraz niskimi dochodami. Patrząc na stopę bezrobocia w pierwszym kwartale 2017 r., wynosiła ona dla poszczególnych regionów: Hauts-de-France (11,7\%), Occitanie (11,2\%), Provence-Alpes-Côte d'Azur 11\%), Korsyka (10,3\%), Normandia (9,6\%), Grand Est (9,5\%), Region

2 Pobrane z: www.interieur.gouv.fr/fr/Elections/Les-resulats/Presidentielles/elecresult_presidentielle 2017/(path)/presidentielle-2017/084/043/index.html, www.thelocal.fr/20170425/ france-presidential-election-the-maps-that-tell-the-story-how-the-frenhc-voted. 
Centralny-Kraj Loary (9\%), Nowa Akwitania (9\%), Burgundia-Franche-Comté $(8,5 \%)$, Île-de-France (8,3\%), Owernia-Rodan-Alpy $(8,3 \%)$, Bretania $(8,1 \%)$, Kraj Loary $(8 \%)$.

Tabela 1. Stopa bezrobocia i poparcie wyborcze w regionach dla Marine Le Pen i Emanuela Macrona

\begin{tabular}{|c|c|c|c|}
\hline Region & $\begin{array}{l}\text { Stopa bezrobocia } \\
\text { marzec 2015-kwiecien } \\
2017\end{array}$ & $\begin{array}{l}\text { Poparcie wyborcze } \\
\text { Marine Le Pen } \\
\text { I tura - II tura }\end{array}$ & $\begin{array}{l}\text { Poparcie wyborcze } \\
\text { Emanuel Macron } \\
\text { I tura - II tura }\end{array}$ \\
\hline Hauts-de-France & $12,5 \%-11,7 \%$ & $\mathbf{3 1 , 0 4 \%}-47,06 \%$ & $19,50 \%-52,94 \%$ \\
\hline Occitanie & $12,1 \%-11,2 \%$ & $22,98 \%-37,01 \%$ & $22,32 \%-62,99 \%$ \\
\hline $\begin{array}{l}\text { Provence-Alpes-Côte } \\
\text { d'Azur }\end{array}$ & $11,5 \%-11,1 \%$ & $28,16 \%-44,53 \%$ & $18,94 \%-55,47 \%$ \\
\hline Korsyka & $11 \%-10,2 \%$ & $\mathbf{2 7 , 8 8} \%-48,52 \%$ & $18,48 \%-51,48 \%$ \\
\hline Normandia & $10,2 \%-9,5 \%$ & $23,93 \%-38,04 \%$ & $22,36 \%-61,96 \%$ \\
\hline Grand Est & $10,2 \%-9,4 \%$ & $\mathbf{2 7 , 7 8 \%}-42,06 \%$ & $20,72 \%-57,94 \%$ \\
\hline $\begin{array}{l}\text { Region Centralny- } \\
\text {-Kraj Loary }\end{array}$ & $9,6 \%-8,9 \%$ & $23,08 \%-36,68 \%$ & $22,68 \%-63,32 \%$ \\
\hline Nowa Akwitania & $9,7 \%-9 \%$ & $14,78 \%-31,35 \%$ & $25,12 \%-68,65 \%$ \\
\hline $\begin{array}{l}\text { Burgundia-Franche- } \\
\text {-Comté }\end{array}$ & $9,3 \%-8,4 \%$ & $25,09 \%-39,52 \%$ & $21,89 \%-60,48 \%$ \\
\hline Île-de-France & $8,8 \%-8,2 \%$ & & \\
\hline Owernia-Rodan-Alpy & $8,9 \%-8,3 \%$ & $20,72 \%-32,87 \%$ & $\mathbf{2 4 , 5 0} \%-67,13 \%$ \\
\hline Bretania & $8,8 \%-8,1 \%$ & $15,33 \%-24,64 \%$ & $29,05 \%-75,36 \%$ \\
\hline Kraj Loary & $8,9 \%-8 \%$ & $18,41 \%-27,58 \%$ & $26,27 \%-72,42 \%$ \\
\hline
\end{tabular}

Źródło: www.ceicdata.com/en/france/unemploymeny-by-region-and-zone?page=2; www.interieur. gouv.fr/Elections/Les-resultats/Presidentielles/elecresult_presidentielle-2017/(path)/presidentielle-2017/093/093.html.

Różnice pomiędzy regionami nie są może znaczące, ale wyraźnie widać korelację pomiędzy stopą bezrobocia a poparciem dla kandydatów. Le Pen wygrała zdecydowanie na północy kraju, gdzie skoncentrowane są tradycyjne gałęzie przemysłu, które znajdują się w coraz większym kryzysie. W regionach tych prowadziła kampanię opartą na hasłach powstrzymania migracji, ponownej industrializacji i ochrony francuskiego przemysłu oraz renegocjacji francuskich związków (warunków uczestnictwa) z Unią Europejską. Dwa departamenty, w których wygrała (Pas de Calais oraz Aisne), mają wysoką stopę bezrobocia 
pomiędzy $12-14 \%$, co jest wynikiem powyżej średniej dla kraju. Generalnie rzecz biorąc, regiony z wysoką stopą bezrobocia (północ i południe), sięgającą powyżej średniej krajowej, głosowały na Le Pen. Można wysnuć wniosek, że antyglobalizacyjna agenda Le Pen uzyskała wsparcie w regionach, w których deindustrializacja doprowadziła do pauperyzacji i wzrostu bezrobocia.

Macron uzyskał zdecydowanie większe wsparcie niż Le Pen wśród wyborców o wysokim poziomie wykształcenia. Ponadto charakterystyczny jest fakt, iż agenda polityczna Macrona uzyskała popularność wśród wyborców wielkomiejskich (Macron uzyskał największe wsparcie w wielkich miastach np. w Paryżu 9 na 10 wyborców głosowało na jego kandydaturę), natomiast Marine Le Pen uzyskała poparcie prowincjonalnej Francji, uzyskując wsparcie w głównie regionach wiejskich. W tym wypadku istotną zmienną jest miejsce zamieszkania. Przykładem takiego podziału może być m.in. departament Gironde, gdzie Macron wygrał, uzyskując ponad 70\% głosów, ale jego elektorat skoncentrowany był w mieście Bordeaux, natomiast Le Pen wypadała zdecydowanie lepiej na prowincji ${ }^{3}$.

Ogólnie mówiąc, Le Pen wygrała w regionach $\mathrm{z}$ wysoką stopą bezrobocia i niskimi dochodami, gdzie swoją kampanię oparła na żądaniach powstrzymania migracji i renegocjacji warunków uczestnictwa Francji w UE. Le Pen zdominowała także obszary wiejskie, głównie na północy i południowym wschodzie. Macron dominował w obszarach dynamicznie rozwijających się ekonomicznie (np. Paryż, Bordeaux), gdzie jego program, odwołujący się haseł przyjaznych biznesowi oraz progresywnych społecznie, uzyskał akceptację wśród wysoko wykształconych wyborców. Zdominował on regiony północno-zachodnie, centralne, oraz południowo-zachodnie.

Analizę zmiennych socjoekonomicznych związanych ze zróżnicowaniem przestrzennym zachowań wyborczych we Francji warto połączyć z analizami aksjologicznego wymiaru francuskiej polityki i zwrócić uwagę na główne linie konfliktów ideologicznych, strukturyzujących francuską sceną polityczną. W dwóch analizach prowadzonych po ostatnich wyborach prezydenckich (EnEF 2017 i FES 2017), aby zrozumieć źródła postaw wyborczych i nowych podziałów politycznych, wzięto pod uwagę zmienne ideologiczne, które występują w różnych kombinacjach w obrębie francuskich grup wyborców.

${ }^{3}$ Pobrane z: www.interieur.gouv.fr/fr/Elections/Les-resulats/Presidentielles/elecresult_presidentielle-2017/(path)/presidentielle-2017/084/043/index.html, www.thelocal.fr/20170425/ france-presidential-election-the-maps-that-tell-the-story-how-the-frenhc-voted. 
W pierwszej rundzie startowali Emanuel Macron - kandydat oferujący nowa agendę polityczną, odwołujący się do tzw. politycznego progresywizmu, ale także do populizmu (określany niekiedy jako „centrowy populista”), wypowiadający się w kategoriach „ponowoczesnych” wartości kulturowych (proimigracyjny, za prawami dla osób homoseksualnych itp.), oraz w kategoriach gospodarczego liberalizmu (pro-austerity, pro-bussines) - 24\%; Marine Le Pen określano jako skrajnie prawicowa populistka, z programem antyeuropejskim i antymigracyjnym, wypowiadająca się przeciwko ekonomicznej globalizacji i masowej migracji - 21,3\% ${ }^{4}$; François Fillon, polityk „mainstreamowy”, republikanin-konserwatysta, zwolennik neoliberalnych reform, a zarazem społeczny konserwatysta (zarówno w kwestii praw dla osób homoseksualnych, jak w kwestiach francuskiej tożsamości) - 20\%; Jean-Luc Mélenchon - określany jako skrajnie lewicowy populista, przeciwnik gospodarki wolnorynkowej, domagający się rewizji traktatów UE, odwołujący się do haseł tradycyjnej lewicy (redystrybucja dochodów, interwencjonizm państwa) oraz do haseł ruchu zielonych (przeciwko energetyce jądrowej, za alternatywnym ekonomicznym modelem rozwojowym) - 19,6\%; Benoît Hamon - należący do partii „głównego nurtu” socjalista - 6,4\%.

W badaniu EnEF z 2017 r., przeprowadzonym przez CEVIPOF, wykorzystane zostały dwie charakterystyki wyborcy: poziom zadowolenia z życia (life satisfaction - LS) oraz poziom zaufania społecznego (inter-personal trust IPT), które powiązano $\mathrm{z}$ aspektami socjoekonomicznymi, takimi jak dochód i wykształcenie czy też status społeczny rodziny ${ }^{5}$. Badania wskazują, że wyborcy Marine Le Pen oraz Jean-Luc Mélechona mieli niższy LS, podczas gdy wyborcy Filona i Macrona mają wysoki poziom LS. W przypadku zmiennej IPT wyborcy

${ }^{4}$ Warto podkreślić, że wynik Marine Le Pen w pierwszej rundzie wyborów prezydenckich wydaje się poniżej przewidywań. Kierowany przez Marine Le Pen Front narodowy odniósł wielki sukces w wyborach do parlamentu europejskiego w 2014 r., zdobywając 24,9\%. W 2015 r. w wyborach do władz departamentów Front Narodowy uzyskał 25,24\% (w pierwszej turze), a w wyborach regionalnych uzyskał aż 27,73\% głosów. Wynik Marine Le Pen w wyborach prezydenckich jest zatem niższy niż uzyskiwała jej partia w wyborach do lokalnych parlamentów.

${ }^{5}$ Wybór takich zmiennych podyktowany jest faktem, że „klasyczne” zmienne związane z wymiarem lewica-prawica, jak na przykład dochód i stosunek do redystrybucji bogactwa, nie wyjaśniają istniejących podziałów Wyborcy Le Pen (skrajna prawica) i Mélechona (skrajna lewica) mają niski poziom dochodów. Jednocześnie jednak różni ich stosunek do problemu redystrybucji bogactwa. Wyborcy Le Pen są wobec takiego rozwiązywania problemów społecznych zdecydowanie bardziej sceptyczni. Wyborcy Flilona i Macrona należą do grupy osób z wysokimi dochodami, przy czym wyborcy Filona (konserwatywna prawica) sprzeciwiają się wszelkim pomysłom redystrybucyjnym. Natomiast wyborcy Macrona (liberalne centrum) uważają to za dopuszczalny środek prowadzenia polityki społecznej. 
Macrona i Mélechona mieli wysokie IPT, wyborcy Filona niski poziom IPT, a ekstremalnie niski poziom IPT - wyborcy Le Pen. Wydaje się więc, że zarówno ugrupowania skrajnie prawicowe, jak i skrajnie lewicowe przyciągają wyborców „rozczarowanych”, o niskim poziomie LS, dla których zachodzące przemiany społeczno-gospodarcze skutkują obniżeniem poziomu życia i rosnącym poczuciem niepewności. Wyborcy z niskim poziomem IPT są sceptyczni co do możliwości realizacji nowego francuskiego „kontraktu społecznego”, natomiast wyborcy z wysokim poziomem IPT wierzą w możliwość nowego „kontraktu społecznego”, która zapewni nie tylko rozwój, ale także skuteczną redystrybucję dochodów (Algan, Beasley, Cohen, Foucault, 2018, s. 3-4).

W badaniu EnEF 2017 analizowano także kwestie ideologiczne, szukając nowych elementów wpływających na podejmowanie decyzji wyborczych. Wzięto pod uwagę cztery grupy zmiennych: 1) Poglądy o charakterze moralnym, jak np. akceptacja do homoseksualnego stylu życia czy stosunek wobec imigracji, gdzie występuje silna opozycja pomiędzy wyborcami Mélechona i Macrona a wyborcami Filona i Le Pen; 2) Poglądy o charakterze ekonomicznym, takie jak redystrybucja dochodów i solidarność społeczna, które nie są główną determinantą głosowania dla zwolenników Macrona i Le Pen, natomiast mocno wpływają na postawy wyborców Filona i Mélechona; 3) Poglądy populistyczne, takie jak brak zaufania do elit politycznych czy też do rządu, ukazują zróżnicowanie pomiędzy wyborcami Le Pen i Mélechona z jednej strony, a Filona i Macrona z drugiej strony; i wreszcie 4) Otwartość, obejmująca m.in. postawy proeuropejskie, nacjonalistyczne, w której widoczna jest silna opozycja pomiędzy wyborcami Le Pen i Macrona, przy czym ta grupa problemów pozostaje relatywnie mało relewantna dla wyborców Filona i Mélechona.

W badaniu FES z 2017 r. wzięto natomiast pod uwagę sześć grup wartości związanych z: autorytaryzmem, ekologizmem, etnocentryzmem, ekonomiczną globalizacja, liberalizmem ekonomicznym oraz społecznym konserwatyzmem. Uznano, iż są to główne punkty odniesienie przy wyborze sposobu głosowania, a współczesna rywalizacja polityczno-partyjna jest strukturyzowana przez tych sześć podstawowych grup wartości. Na tej podstawie skonstruowano obraz specyficznego układu pola rywalizacji politycznej, strukturyzowanego przez linie podziałów związane z wartościami: 1) narodowo-nacjonalistycznymi, anty-imigranckimi i autorytarnymi; 2) produktywistycznymi, proglobalizacyjnymi, neoliberalnymi; 3) kosmopolitycznymi, proimigranckimi, libertariańskimi; 4) ekologizmem, anty-globalizmem i interwencjonizmem. Francuscy badacze sugerują, że współczesne pole polityki jest strukturyzowane przez dwa podstawowe 
osie konfliktów. Pierwsza z nich tworzy dominujący obecnie podział, który opiera się na przeciwstawieniu wartości nacjonalistycznych/antyimigracyjnych/autorytarnych wartościom kosmopolitycznym/pro-imigranckiem/libertariańskiem. Druga związana jest $\mathrm{z}$ konfliktem pomiędzy produktywizmem, neoliberalizmem i globalizmem, ekologizmem/anty-globalizmem/interwencjonizmem (Gougou, Persico, 2017, s. 303).

Mamy zatem do czynienia $\mathrm{z}$ dwoma nowymi osiami wartości, które wyznaczają linie konfliktów politycznych. Stanowią nowy układ odniesienia przy podejmowaniu decyzji wyborczych, a rywalizacja polityczna odbywa się w wyznaczanej przez nie przestrzeni. Każda z partii i każdy z polityków może zostać umiejscowiony w jednym $\mathrm{z}$ pól wyznaczanych przez oś 1 i oś 2 , w zależności od wartości preferowanych przez swoich wyborców.

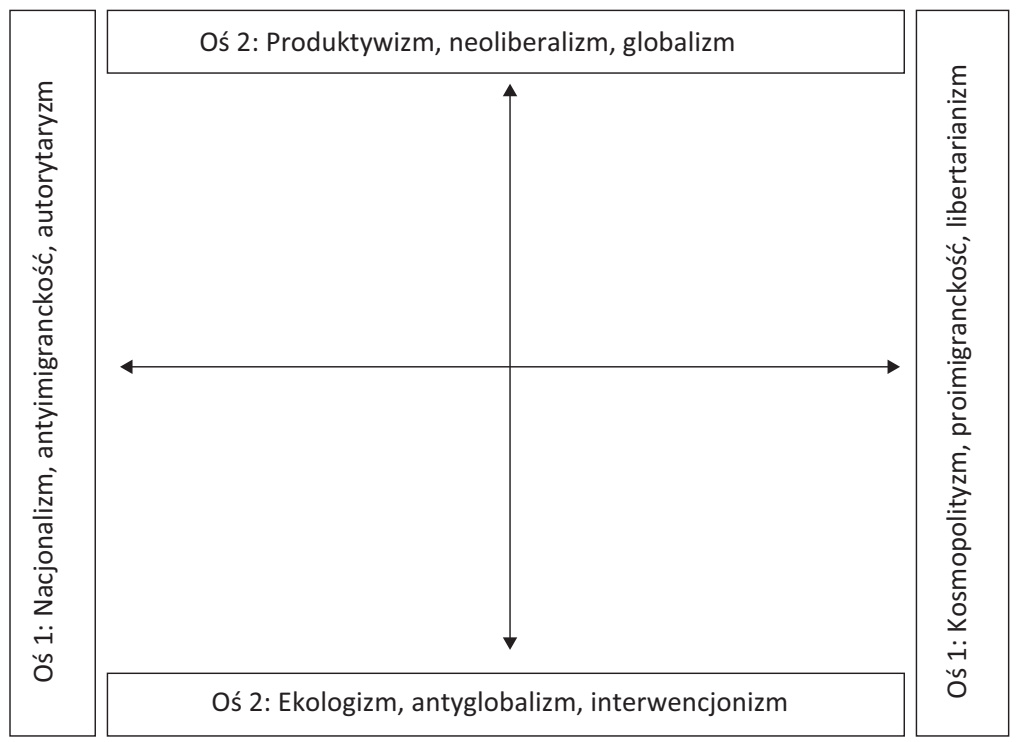

Rys 1. Wymiary rywalizacji politycznej

W tym ujęciu na osi 1 wyborcy Macrona i Mélechona są zwolennikami wartości nr 3 (kosmopolityczne, proimigranckie, libertariańskie) i nie ma zbyt dużych różnic między nimi. Wyborcy Le Pen i Filona są bliżsi wartościom nr 1 (narodowo-nacjonalistycznym, antyimigranckim i autorytarnym), przy czym występują znaczące różnice między bardziej radykalnymi wyborcami Le Pen a bardziej umiarkowanymi wyborcami Filona. Na osi 2 zwolennikom Filona 
i Macrona są bliskie wartości nr 2 (produktywistyczne, proglobalizacyjne, neoliberalne), przy czym wyborcy Macrona są w tym względzie zdecydowanie bardziej umiarkowani, zbliżając się do centrum. Wartości nr 4 (ekologizm, antyglobalizm, interwencjonizm) zbliżają do siebie wyborców Le Pen i Mélechona, przy czym ci ostatni są zdecydowanie radykalniejsi, a zwolennicy Le Pen bardziej umiarkowani w swoich postawach odnoszących się do tej sfery. W tym wypadku dla wyborców Le Pen główną kwestią jest przede wszystkim antyglobalizm (por. Gougou, Persico, 2017, s. 312-314), a dla wyborców Mélechona kwestie ekologii.

\section{REWOLUCJA POSTNARODOWA I POSTINDUSTRIALNA JAKO ŹRÓDŁO NOWYCH PODZIAŁÓW SPOŁECZNYCH}

Zmienne przyjęte w badaniu EnEF 2017 i FES 2017 są do siebie podobne i wskazują na nowe linie konfliktów ideologicznych, które w największym stopniu strukturyzują współczesną scenę polityczną we Francji i jednocześnie wykraczają poza klasyczny układ lewica-prawica. Połączenie ich z danymi związanymi z przestrzennym zróżnicowaniem głosowania we francuskich departamentach pozwala na dokonanie pewnych uogólnień dotyczących źródeł współczesnych konfliktów politycznych.

Szukając odpowiedzi na pytanie o źródła nowych podziałów politycznych, warto bliżej przyjrzeć się sytuacji, w której mamy do czynienia z czterema „blokami” politycznymi. Jeżeli weźmiemy pod uwagę fakt, że we współczesnej rywalizacji politycznej z jednej strony następuje podział na protekcjonizm i globalizm, a $\mathrm{z}$ drugiej zaś na nacjonalizm i transnacjonalizm, to $\mathrm{w}$ sensie analitycznym możemy mówić o czterech nowych podstawowych podziałach socjopolitycznych w ramach struktury społecznej, które prowadzą do konfliktu grup interesów i rywalizacji partii politycznych w ramach systemu partyjnego. Podział ten może służyć jako punkt wyjścia do bardziej szczegółowych analiz.

Układ ten związany jest z próbą szukania ideologiczno-politycznej odpowiedzi na wyzwania współczesności związane z rewolucją postanrodową i postindustrialną. Rewolucja postnarodowa (denacjonalizacja, transnacjonalizacja) ma dwa podstawowe wymiary: polityczny i społeczny. W wymiarze politycznym przejawia się w tendencji do tworzenia supranarodowych ugrupowań polityczno-gospodarczych, przejmujących kompetencje dotychczasowych państw narodowych i ograniczających ich suwerenność. W wymiarze społecznym oznacza kształtowanie się hybrydowych społeczeństw (wielokulturowych) i hybrydowych 
tożsamości indywidualnych, czerpiących siłę z wielu źródeł i praktyk kulturowych. Kształtuje ona charakterystyczne linie podziałów politycznych. Jedną linią podziału jest opozycja pomiędzy scentralizowanym państwem narodowym i jego tradycyjnymi elitami społecznymi przywiązanymi do idei terytorialnej suwerenności oraz kosmopolitycznymi elitami społeczno-politycznymi, operującymi $\mathrm{w}$ przestrzeni ponadnarodowej. W wymiarze społecznym linia podziału przebiega pomiędzy zwolennikami budowy otwartego, wielokulturowego społeczeństwa, a zwolennikami tradycyjnych wartości, zakorzenionych w lokalnej kulturze, kwestionujących możliwość istnienia stabilnych społeczeństw wielokulturowych. Rewolucja postanarodowa jest zatem odpowiedzialna za ukształtowanie się linii konfliktów politycznych wyznaczanych na rysunku przez oś 1 .

Rewolucja postindustrialna związana jest natomiast $\mathrm{z}$ głęboką transformacją instytucji gospodarczych, a w tym z głęboką integracją lokalnych gospodarek z gospodarką globalną (neoliberalna globalizacja), przesunięciem dominujących światowych gospodarek od wytwórczości do usług (deindustrializacja), a także entuzjastycznym wprowadzaniem nowych technologii (robotyzacja, informatyzacja, automatyzacja - przemysł 4.0). Rewolucja ta kształtuje linie podziału pomiędzy regionami z gospodarką postindustrialną, powiązaną globalnie, regionami czerpiącymi zyski z procesów neoliberalnej globalizacji oraz regionami z gospodarką industrialną, dotkniętymi procesami deindustrializacji, a tym samym bezrobociem oraz pauperyzacją społeczną. Drugą linią podziału stworzoną przez rewolucję postidustrialną jest podział pomiędzy wysoko wykfalifikowaną, postindustrialną siłą roboczą, funkcjonującą w ramach elastycznych technik organizacji pracy, a sprekaryzowanymi grupami społecznymi, dla których automatyzacja, robotyzacja i ucieczka miejsc pracy do regionów o niższych kosztach (offshoring) oznacza brak stabilności zawodowej i brak miejsca na rynku pracy (por. Potulski, 2018, s. 165-168). Rewolucja postindustrialna jest zatem odpowiedzialna za ukształtowanie się podziałów politycznych wyznaczanych na rysunku przez oś 2 .

W wyniku przemian, jakie następują w społeczeństwach wysokorozwiniętych, zwraca się uwagę na coraz silniejsze podziały społeczne i istniejący rozdźwięk pomiędzy kosmopolitycznymi elitami i populistycznie nastawioną większością. Transformacja społeczna, która dotyka wysokorozwinięte społeczeństwa europejskie, budzi także opór przed konsekwencjami zachodzących zmian. Fala kontrmobilizacji przetaczająca się przez kraje europejskie określana jest jako „populistyczna” przede wszystkim dlatego, że jest skierowana przeciwko dotychczasowemu konsensusowi politycznemu i elitom politycznym, które go 
utożsamiają. Coraz częściej można dostrzec, że z jednej strony mamy globalne metropolie, będące „wyspami” dobrobytu, a po drugiej peryferie małych i średnich miast, dawnych obszarów przemysłowych i dalekich obszarów wiejskich. Metropolie to „symbole” globalizacji i jej konsekwencji - wielokulturowości, gdzie obok siebie mieszkają „nowa burżuazja” i kolorowa różnorodność migrantów. Na peryferiach koncentrują się środowiska, które kiedyś nic nie łączyło: robotnicy, zwykli urzędnicy, zatrudnieni na śmieciowych umowach, rolnicy, drobni przedsiębiorcy, emeryci, wszyscy złączeni wspólnym poczuciem podwójnej niepewności: finansowej i kulturowej. Procesy związane z rewolucją postanarodową i rewolucją postindustrialną przyniosły im podwójny niepokój: finansowy - związany z niestabilnością gospodarczą, pauperyzacją i brakiem pracy, oraz kulturowy - związany z rosnącym napływem migrantów z innych stron świata. Lęki te mają swoje odzwierciedlenie w zachowaniach wyborczych i w największym stopniu wpływają na współczesne podziały społeczne politycznie doniosłe.

\section{ZAKOŃCZENIE}

Po ostatnim cyklu wyborczym we Francji (wybory regionalne, prezydenckie i parlamentarne) widoczne jest ukształtowanie się czterech bloków politycznych, które w największym stopniu strukturyzują scenę polityczną. W tym przypadku bardzo charakterystyczny jest fakt, że w pierwszej rundzie wyborów prezydenckich czterech kandydatów uzyskało zbliżony do siebie wynik. Możliwych jest zatem kilka scenariuszy nowego układu sił. W pierwszym scenariuszu dojdzie do ukształtowania się czterech bloków politycznych: Macron reprezentujący nowy centrowo-liberalny (progresywizm) program; Mélechon reprezentujący nową, radykalną lewicę; Fillon reprezentujący tradycyjny, umiarkowany konserwatyzm; i wreszcie Marine Le Pen reprezentująca nową populistyczną prawicę. W drugim scenariuszu możliwy jest standardowy model trójpartyjny (tripolarity), w którym Macron zajmuje dotychczasowe miejsce Partii Socjalistycznej, tworząc centrowo-lewicową koalicję z zielonymi, natomiast prawa strona sceny partyjnej pozostaje podzielona pomiędzy obóz konserwatywny reprezentowany przez Fillona i daleką prawicę, reprezentowaną przez Marine Le Pen. Trzeci scenariusz zakłada ukształtowanie się nowego modelu trójpartyjnego, odmiennego od dotychczasowego porządku politycznego, z Macronem reprezentującym „nowe centrum”, zdecydowanie odcinającym się od lewicy reprezentowanej przez Mélechona. 
Na prawej stronie sceny politycznej porozumienie między dwoma odłamami prawicy, która jednoczy się pod przewodnictwem bardziej umiarkowanego przywódcy. W tym scenariuszu kształtują się trzy pola rywalizacji politycznej: eko-socjalistyczna, liberalno-globalizacyjna oraz konserwatywna. W czwartym scenariuszu układ czterech bloków politycznych ewoluuje w kierunku klasycznego układu dwublokowego, w którym nowe linie konfliktów politycznych zostają skanalizowane w układzie dwóch sojuszy partyjno-politycznych, które można analizować w kategoriach lewica-prawica (Gougou, Persico, 2017, s. 304, 310).

Niezależnie od tego, w jakim kierunku będzie ewoluowała struktura francuskiego system partyjnego, ważne pozostają główne zmienne, które determinują współczesne postawy polityczne. Pod koniec lat 70. Ronald Inglehart przekonywał, że taką podstawową zmienną jest przejście od wartości materialistycznych do postmaterialistycznych. Obecnie na ten podział nałożyły się rewolucje postnarodowa i postindustrialna. To te elementy stanowią o swoistości współczesnych konfliktów politycznych. Chcąc je zrozumieć, należy je analizować w kontekście głębokiej transformacji cywilizacyjnej zachodzącej na poziomie makro. Dlatego też analiza zmian zachodzących we francuskim systemie politycznym ma nie tylko znaczenie poznawcze, ale służy dla ukazania pewnych uniwersalnych tendencji, które występują we współczesnej Europie.

Zaproponowany przez francuskich badaczy wymiar rywalizacji politycznej z podziałem na jej cztery nowe pola wydaje się być narzędziem, które może być stosowane do każdego współczesnego europejskiego systemu partyjnego. W zależności od lokalnej specyfiki w każdym kraju można będzie obserwować pewne odrębności, ale podstawowe zależności i korelacje powinny ujawniać podobieństwa. Dzięki badaniom porównawczym można dostrzec pewne uniwersalne wzorce pojawiające się także w pozostałych krajach europejskich.

Niezależnie od faktu, że istniejące układy partyjne zależą także od lokalnych tradycji politycznych, to wszędzie można podjąć próbę zastosowania podobnego schematu wyjaśniającego. Porównując np. ewolucję systemu partyjnego Francji i Polski, można dostrzec, że w przypadku Polski prawa strona sceny politycznej została zdominowana przez szeroki konserwatywny ruch odwołujący się do haseł etnonacjonalistycznych, społecznie konserwatywnych i antykosmopolitycznych. W centrum mamy do czynienia z szeroką koalicją sił centrowo-liberalnych, a po lewej stronie sceny politycznej zaczyna się powoli kształtować wielkomiejska „nowa lewica”, odwołująca się do ekologizmu i radykalnych haseł społecznych, odcinająca się centrowo-liberalnej koalicji politycznej. Takie ukształtowanie 
się dominujących linii podziałów, podobnie jak i we Francji, związane jest $\mathrm{z}$ rozprzestrzenieniem się tzw. wartości postmaterialistycznych, a także dwiema „rewolucjami” społecznymi, których doświadczyły społeczeństwa europejskie w ostatnich trzech dekadach gwałtownych zmian społecznych: rewolucją postnarodową i rewolucją postindustrialną.

\section{BiBLIOGRAFIA:}

Algan, Y., Beasley, E., Cohen, D., Foucault, M. (2018). The rise of populism and the collapse of the left-right paradimg: Lessons from the 2017 French presidential election, CEMREMAP, Document de travail, (Docweb), no 1805. Pobrane z: www.cepremap. fr/depot/2018/10/docweb/1805.pdf).

Beck, U., Giddens, A., Lash, S. (2009). Modernizacja refleksyjna: polityka, tradycja i estetyka w porzadku społecznym nowoczesności. Warszawa: PWN.

Bornschier, S. (2010a). The new cultural divide and the two-dimensional political space in Western Europe. West European Politics, 33(3), 419-444.

Bornschier, S. (2010b). Cleavage politics and the populist right. Philadelphia: Temple University Press.

Clark, T.N., Lipset, S.M., Rempel, M. (1993). The declining political significance of social calss. International Sociology, 8(3), 293-316.

Clark, T.N, , Lipset, S.M., (1991). Are social classes dying?. International Sociology, 6(4), 397-410.

Dalton, R.J, Flanagan, S.C., Beck, P.A. (eds.). (1984). Electoral change in advanced industrial democracies. Realignment or dealignment? Princeton, NJ, Princeton University Press.

Dalton, R.J. (1984). Cognitive mobilization and partisan dealignment in advanced industrial democracies. The Journal of Politics, 46(1), 264-284.

de Graaf, N.D., Heath, A., Need A. (2001). Declining cleavages and political choices: the interplay of social and political factors in the Netherlands. Electoral Studies, $20,1-15$.

Knutsen, O. (2006). Class voting in Western Europe: a comparative longitudinal study. Lanham: Lexington

Franklin, M.M., Mackie, T.T., Valen H. (1992). Electoral change: responses to evolving social and attitudinal structures in Western Countries. Cambridge: Cambridge University Press.

Giddens. A. (2001). Poza lewica i prawica: przyszłość polityki radykalnej. Zysk i S-ka, Poznań: Zysk i S-ka.

Gougou, F., Persico, S. (2017). A new party system in making? The French presidential elections. French Politics, 15, 303-321.

Hooghe, L., Marks, G. (2018). Cleavage theory meets Europe's crises: Lipset, Rokkan, and the transnational cleavage. Journal of European Public Policy, 25(1), 109-135. 
Inglehart, R. (1977). The silent revolution. Changing values and political styles among western publics. Princeton: Princeton University Press.

Inglehart, R. (1984). The changing structure of political cleavages in western society. W: P.A. Beck, S.C. Flanagan, R.J. Dalton (red.). Electoral change in advanced industrial democracies: realignment or dealignment? (s. 25-69). Princeton: Princeton University Press.

Kiresi, H., Grande, E., Dolezal, M., Helbling, M., Höglinger, D., Hutter, S., Wüest, B. (2012). Political conflict in Western Europe. Cambridge: Cambridge University Press.

Kitschelt, H.P., Staf, H. (1990). The left-right semantics and the new political cleavage. Comparative Political Studies, 23(2), 210-238.

Kitschelt, H.P. (1988). Left-libertarian parties: explaining innovation in competitive party systems. World Politics, 40(2), 194-234.

Kriesi, H., Grande, E., Lachat, R., Dolezal, M., Bornschier, S., Frey T. (2006). Globalization and the transformation of the national political space: six European countries compared. European Journal of Political Research, 45, 921-956.

Kriesi, H., Grande, E., Lachat, R., Dolezal, M., Bronschier, S., Frey, T. (2008). West European politics in the age of globalization. Cambridge: Cambridge University Press.

Laclau, E. (2009). Rozum populistyczny. Wrocław: Wydawnictwo Dolnośląskiej Szkoły Wyższej Edukacji.

Lipset, S.M., Rokkan, S. (1967). Party systems and voter alignments: cross-national perspectives. New York: The Free Press.

Nieuwbeerta, P.,Ultee, W. (1999). Class voting in western industrialized countries, 1945-1990: systematizing and testing explanations. European Journal of Political Research, 35(1), 123-160.

Potulski, J. (2018). Zwycięstwo wyborcze Donalda Trumpa jako przykład drugiej fali kontr mobilizacji. W: J. Misiuna, M. Molęda-Zdziech, S. Łubiarz (red.). Amerykańskie wybory prezydenckie w erze postprawdy (s. 157-180). Warszawa: Oficyna Wydawnicza.

Potulski, J. (2014). Post-polityka - polityka w społeczeństwie informacyjnym. Athenaeum, 43, 54-76.

Scholte, A. (2006). Globalizacja: krytyczne wprowadzenie. Sosnowiec: Oficyna Wydawnicza Humanitas.

Stewart, A. (1969). The social roots. W: Populism. Its meaning and national characteristic. London.

Szacki, J. (2006). Populizm, a demokracja. W: M. Marczewska-Rytko (red.). Populizm na przełomie XX i XXI wieku. Panaceum czy pułapka dla współczesnych społeczeństw? Toruń: Wydawnictwo Adam Marszałek. 